Trace-Element Contents of Some Plutonic Rocks of the Sierra Nevada Batholith

GEOLOGICAL SURVEY BULLEXIN I I I4-F 
• 


\section{Trace-Element Contents of Some Plutonic Rocks of the Sierra Nevada Batholith}

By F. C. W. DODGE

\section{GONTRIBUTIONS TO GEOCHEMISTRY}

GE O L O G C A L S U R V E Y B U L L E T I N $1314-\mathrm{F}$

Summary of available trace-element data giving average data for 20 elements and other data for an additional 26 elements

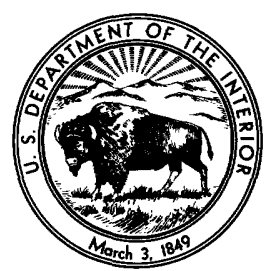




\section{UNITED STATES DEPARTMENT OF THE INTERIOR}

ROGERS C. B. MORTON, Secretary

\section{GEOLOGICAL SURVEY}

V. E. McKelvey, Director

Library of Congress catalog-card No. 72-600055

For sale by the Superintendent of Documents, U.S. Government Printing Office Washington, D.C. 20402 - Price 55 cents (paper cover) 


\section{CONTENTS}

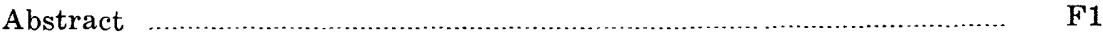

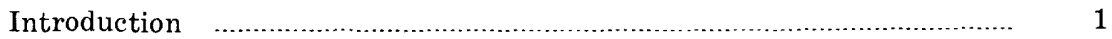

Abundance and variation of trace elements ....................................... 2

Changes in trace-element contents across the batholith ....................... 5

Discussion ................................................................................ 8

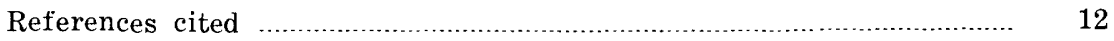

\section{ILLUSTRATIONS}

Plate 1. Trace-element concentrations of plutonic rocks, central Sierra Nevada batholith ............................................ In pocket

FIgURE 1. Map of central California and western Nevada showing distribution of granitic rocks of the Sierra Nevada batholith

2. Histograms of trace-element contents of the plutonic rocks of the Sierra Nevada

3-5. Graph showing-

3. Rubidium contents of granitic rocks

4. Lines representing least-squares approximations of uranium and thorium contents

5. Comparison of average and ranges of traceelement contents of Sierra Nevada

\section{TABLES}

TABLE 1. Selected minor-element data for Sierra Nevada Mesozoic plutonic rocks

Page

F4

2. Average major-element-oxide compositions of Sierra Nevada Mesozoic plutonic rocks 



\title{
CONTRIBUTIONS TO GEOCHEMISTRY
}

\section{TRACE-ELEMENT CONTENTS OF SOME PLUTONIC ROCKS OF THE SIERRA NEVADA BATHOLITH}

\author{
By F. C. W. Dodge
}

\begin{abstract}
Trace-element analyses on plutonic rocks of the Sierra Nevada batholith show that, in general, average abundances of elements determined are similar to abundances of high-calcium granites of the earth's crust. Average data for 20 elements were used, along with some other data for an additional 26 elements. The large, highly coordinated trace elements are more abundant in Sierra Nevada plutonic rocks than in calc-alkaline circumPacific andesites, whereas many other elements are about the same as, or slightly less abundant than, in andesites.

Lateral changes across the central Sierra Nevada batholith are well defined for beryllium, uranium, thorium, and rubidium, all of which systematically increase eastward. Other trace elements exhibit less convincing trends of lateral variation. Causes of lateral variations of the trace elements are incompletely known, but are undoubtedly related to compositional changes of major chemical constituents, in particular $K_{2} O$. The trends may reflect crustal chemical variation which existed before batholith emplacement.
\end{abstract}

\section{INTRODUCTION}

Knowledge of overall trace-element chemistry of Mesozoic granitic rocks of the Sierra Nevada batholith is useful to future scientific and economic investigations. Data on trace elements may provide some clues about the origin of the batholith and about batholiths in general and may also provide background information for geochemical studies made in conjunction with mineral surveys in the Sierra Nevada.

Since 1958 many analytical data for several different trace elements have been determined on samples of granitic rocks from the Sierra Nevada batholith in laboratories of the U.S. Geological Survey. In addition, uranium and thorium have been determined on several hundred samples by the Lawrence Radiation Laboratory, Berkeley, Calif., in cooperation with the Geological Survey. As part of a program of geochemical study, trace-element analyses determined before 1971 are here summarized. Data continue to accumulate as geological studies in the batholith pro- 
ceed. This report is a statement of progress and will likely be expanded and refined. Some data upon which this report is based have been presented in published reports; some have not yet been published. The data are mostly geographically restricted to four areas in the central and northern Sierra Nevada (fig. 1), the Bucks Lake and Pulga quadrangles, the Desolation Valley primitive area, the Emigrant Basin primitive area, and a large area between lat. $36^{\circ} 45^{\prime}$ and $38^{\circ} 00^{\prime} \mathrm{N}$., the so-called central Sierra Nevada belt. Trace-element contents have been determined for a variety of purposes. They were determined on samples from the two primitive areas (Dodge and Fillo, 1967; Tooker and others, 1970) and on some samples from the central belt (Lockwood and others, 1972) as integral parts of mineral surveys; on representative rock samples collected during geologic mapping (Bateman, 1965; Bateman and Lockwood, 1970; Bateman and Wones, 1972; Ross, 1969) ; for specific topical studies involving one or relatively few elements (Dodge and others, 1970; Gottfried and others, 1972; Wollenberg and Smith, 1964, 1968). Data on altered or mineralized rocks have been excluded from this compilation; insofar as is known, all determinations are on fresh, unaltered rocks.

The geology of some of the sampled areas has been described in several of the reports referred to. The general geology of the Sierra Nevada has been summarized in several publications (for example, Bateman and others, 1963; Bateman and Eaton, 1967) ; hence, the geology of the region is not discussed here. Because genetic affiliations between different areas of the batholith are as yet incompletely known, there is no attempt here to relate trace-element content to plutonic rock units, as has been done with the major chemical constituents in the central part of the batholith (Bateman and Dodge, 1970). This report includes data on the abundance and variation of trace elements from both the northern and central parts of the batholith, but the discussion of the geographic distribution of trace elements is limited to the central Sierra Nevada belt.

\section{ABUNDANCE AND VARIATION OF TRACE ELEMENTS}

Data compiled on minor elements in rocks of the Sierra Nevada batholith, along with average minor-element contents for high-calcium granites of the earth's crust (Turekian and Wedepohl, 1961) and for circum-Pacific calc-alkaline andesites (Taylor, 1969), are given in table 1. Many of the data are based on values obtained by six-step semiquantitative emission spectro- 


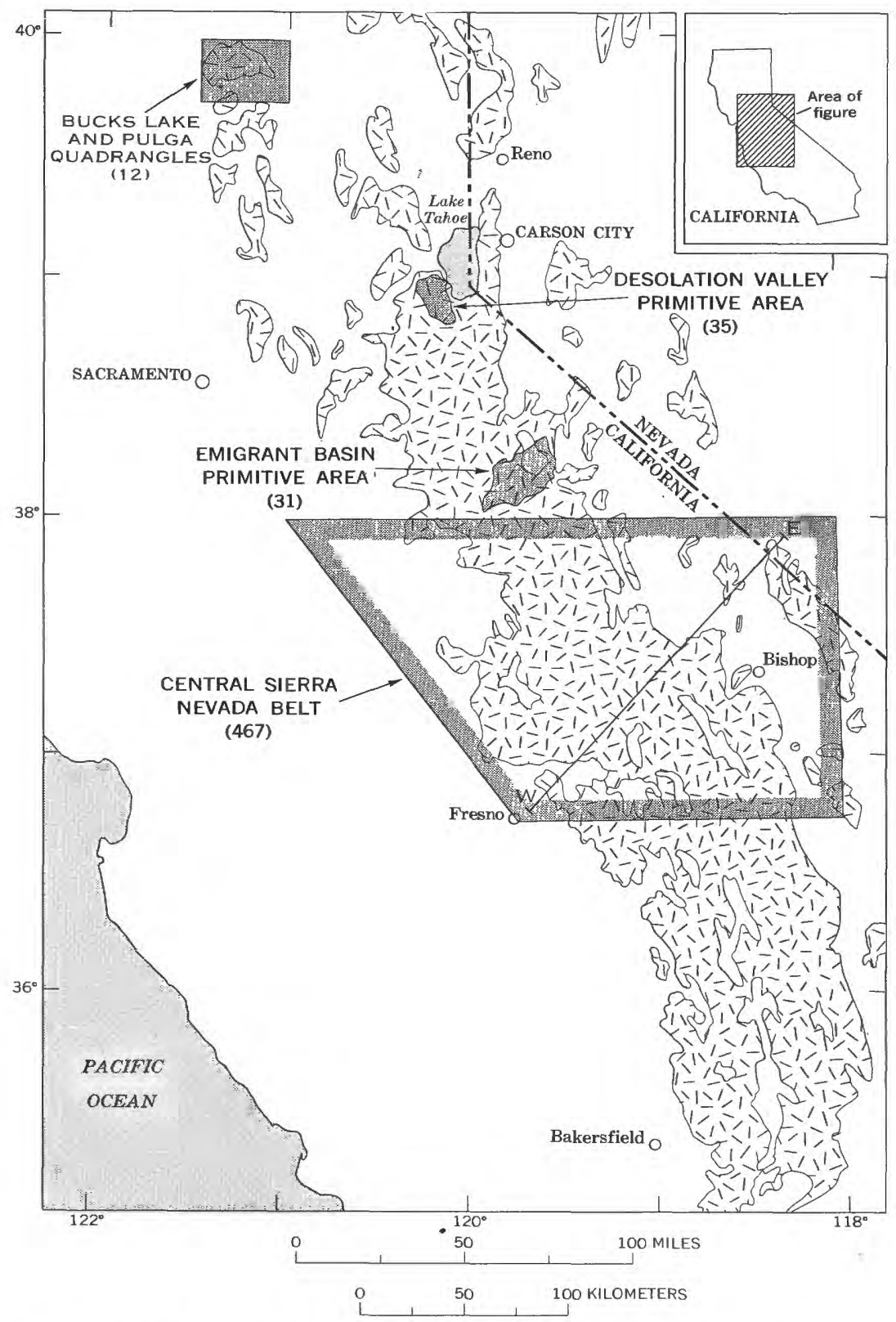

FIGURE 1.-Distribution of granitic rocks of the Sierra Nevada batholith in central California and western central Nevada, and areas from which samples analyzed by the semiquantitative spectrographic method were collected (number of samples analyzed from each area indicated in parentheses). W-E line is projection of plate 1 and figure 3 . 
TABLE 1.- Selected minor-element data, in parts per million, for Mesozoic plutonic rocks of the Sierra Nevada, high-calcium granites of the earth's crust, and circum-Pacific calc-alkaline andesites

\begin{tabular}{|c|c|c|c|c|c|c|c|}
\hline & & Mesozoic & plutonic rocks & of the Sierr & a Nevada & & \\
\hline$\frac{\stackrel{\vec{Z}}{\Xi}}{\stackrel{\Xi}{\Xi}}$ & 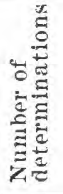 & 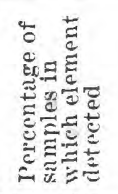 & 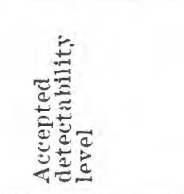 & 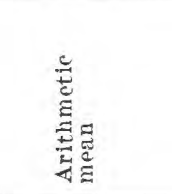 & 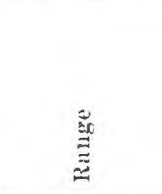 & 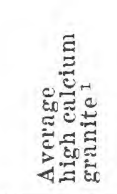 & 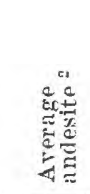 \\
\hline Ast -- & 545 & $<1$ & 1 & $-\infty-\infty-\infty$ & $<1-30$ & 0.051 & 0.13 \\
\hline As $\ldots$ & 71 & 42 & 10 & & $<10 \_40$ & 1.9 & \\
\hline Au & 16 & 100 & .0001 & 0.0012 & $.0003 \_0055$ & .004 & $-\infty--$ \\
\hline$B^{*}--$ & 480 & 27 & 10 & & $<10 \_100$ & & \\
\hline Ba* ... & 545 & 100 & 10 & 1000 & $20-3000$ & 420 & 270 \\
\hline$B \mathbf{e}^{*}$ & 545 & 54 & 1 & 1 & $<1-7$ & 2 & $\ldots$ \\
\hline Bi* - - & 545 & $<1$ & 10 & $-\ldots \ldots$ & $<1-150$ & & $\ldots$ \\
\hline $\mathrm{Cd}$ & 510 & 0 & 50 & $\ldots-\ldots$ & & .13 & \\
\hline $\mathrm{Ce}^{*}-$ & 408 & 2 & 200 & $\ldots$ & $<200-700$ & 81 & 24 \\
\hline Co* -- & 545 & 68 & 5 & 10 & $<5-100$ & 7 & 24 \\
\hline $\mathrm{Cr} *$ & 545 & 86 & 1 & 30 & $<1-1500$ & 22 & 56 \\
\hline $\mathrm{Cu} *$ & 545 & 95 & 1 & 20 & $<1 \_1000$ & 30 & 54 \\
\hline Eu & 159 & 0 & 500 & & & 1.4 & 1.0 \\
\hline Ga* -- & 407 & 100 & 2 & 15 & $<250$ & 17 & 16 \\
\hline Ge* - - & 408 & 0 & 10 & $\ldots-\cdots$ & -------- & 1.3 & $\ldots \ldots$ \\
\hline $\mathrm{H}^{*}$ & 408 & 0 & 100 & $-\cdots-1=-$ & $-----1--$ & 2.3 & $-\ldots$ \\
\hline $\mathrm{Hg} \quad--$ & 29 & 100 & $0^{.01}$ & .15 & .01 .26 & .08 & ---- \\
\hline $\ln _{\mathrm{La}} *-$ & $\begin{array}{l}408 \\
545\end{array}$ & 86 & $\begin{array}{r}0 \\
30\end{array}$ & 30 & $<30 \_150$ & $45^{.0 X}$ & $\overline{11} \overline{9}$ \\
\hline Li* - & 438 & $<1$ & 200 & $-1-1-\ldots$ & $<200-200$ & 24 & $10^{\circ}$ \\
\hline Mo* - & 545 & 4 & 5 & 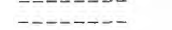 & $<5$ & 1.0 & 1.1 \\
\hline $\mathrm{Nb}^{*}$ & 510 & 46 & 10 & ------- & $<10-50$ & 20 & 4.3 \\
\hline $\mathrm{Nd}^{*}$ & 159 & $<1$ & 100 & - & $<100-150$ & 33 & 13 \\
\hline Ni* -- & 545 & 53 & 5 & 10 & $<5 \_700$ & 15 & 18 \\
\hline $\mathrm{Pb}^{*}$ & 545 & 80 & 10 & 20 & $<10 \_150$ & 15 & 6.7 \\
\hline Pd & 438 & 0 & 3 & $\ldots \ldots-\ldots$ & $-\ldots \ldots-n$ & $.00 \mathrm{X}$ & $-\cdots--1$ \\
\hline $\operatorname{Pr}=-$ & 159 & 0 & 500 & ------ & --------- & 7.7 & 3.2 \\
\hline Pt - - & $\begin{array}{r}438 \\
88\end{array}$ & $\begin{array}{r}0 \\
98\end{array}$ & $\begin{array}{l}30 \\
20\end{array}$ & $118^{-\cdots}$ & $<20-270$ & $110^{---}$ & 31 \\
\hline $\mathrm{Re}$ & 408 & 0 & 50 & 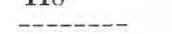 & $-20=280$ & 110 & - n- \\
\hline $\mathrm{Sb}$ & 30 & 3 & .2 & $\ldots$ & $<.2 \ldots \bar{v}$ & .2 & .22 \\
\hline Sc* - & 480 & 70 & 5 & 10 & $<5 \_100$ & 14 & 30 \\
\hline $\mathrm{Sm}$ & 159 & 0 & 100 & -- & - - & 8.8 & 2.9 \\
\hline Sn $\ldots$ & 545 & 0 & 10 & $\ldots$ & - non & 1.5 & .8 \\
\hline Sr** - & 610 & 99 & 10 & 500 & $<10-2000$ & 440 & 385 \\
\hline Ta & 438 & 0 & 200 & $--\infty-\infty-$ & $-\cdots-\infty-1$ & 3.6 & $\cdots \cdots$ \\
\hline Te _- - & 438 & 0 & 1000 & $-1435-$ & $18-501 \overline{1}$ & 85 & $2 \frac{-1}{2}$ \\
\hline Th & $\begin{array}{l}654 \\
438\end{array}$ & $\begin{array}{r}100 \\
0\end{array}$ & $100^{.01}$ & 14.35 & $.18+50.12$ & 8.5 & 2.2 \\
\hline $\mathrm{Ti}=-$ & $\begin{array}{l}438 \\
654\end{array}$ & 100 & $\begin{array}{r}100.01 \\
0\end{array}$ & 4.34 & $.31-29.56$ & 3.0 & .69 \\
\hline$V^{*}-$ & 545 & 93 & $10^{\circ .2}$ & 100 & $<10 \_1500$ & $88^{\circ}$ & $175^{\circ}$ \\
\hline $\mathbf{W}$ & 30 & 10 & 2 & ---- & $<2-20$ & 1.3 & \\
\hline $\mathbf{Y}^{*}$ & 545 & 83 & 10 & 15 & $<10-70$ & 35 & 21 \\
\hline $\mathbf{Y b}^{*}$ & 408 & 83 & 1 & 1.5 & $<1-7$ & 3.5 & 1.9 \\
\hline $\mathrm{Zn}$ & 30 & 27 & 12.5 & & $<12.5 \_37.5$ & 60 & \\
\hline $\mathrm{Zr}$ & 480 & 99 & 10 & 100 & $<10-700$ & 140 & 110 \\
\hline
\end{tabular}

1 From Turekian and Wedepohl (1961).

2 From Taylor (1969).

*Values for Sierra Nevada plutonic rocks based entirely on semiquantitative emission spectrographic analysis. Results reported to the nearest number in the series $1,0.7,0 . \bar{\varepsilon}$ $0.3,0.15,0.1$. See text for discussion of method of reporting average abundances and ranges, of abundances.

* Values for Sierra Nevada plutonic rocks based both on semiquantitative emission spectrographic and on quantitative analyses. Average abundance and range of abundance reported as if all values were semiquantitative.

graphic analysis, a method routinely used in laboratories of the Geological Survey for many years. The convention used in reporting results has been retained in compiling average abundances and ranges of abundance (to the nearest number in the series 1 , 
$0.7,0.5,0.3,0.15,0.1$, and so forth). Spectrographic detectability levels have improved considerably since the first samples were analyzed, but for consistency, the oldest detectability levels available have been quoted. The number of semiquantitative analyses from each of the four areas in the Sierra Nevada is indicated in figure 1.

Contents of some elements have been determined by other methods, including colorimetry, neutron activation, gamma-ray spectrometry, and atomic absorption. Values for these elements are quantitative. Except for the mercury values determined on materials collected from the Emigrant Basin primitive area and a relatively few rubidium and strontium values on materials from scattered areas, all analyses determined by methods other than by emission spectrography are on rocks from the central belt. (Detectability levels of methods used for gold and uranium analyses in the primitive areas are so poor, compared with methods used on materials from the central belt, that the primitive area values have been omitted from the compilation.)

Of the 46 elements listed in table 1, 20 are present in amounts greater than the detectability level given in the table in at least half of the samples in which the element was looked for. Arithmetic means have been calculated for these 20 elements. For analyses in which the element is below the quoted detectability level, a zero value has been assigned and included in calculation of the mean; use of zero values precludes calculation of a geometric mean. Ranges are given for all 32 elements detected, but the lower limit exceeds the detectability level for only five of the elements.

Variation of contents of elements determined spectrographically are depicted by histograms (figure 2) for those elements detected in at least one-third of the samples in which the element was looked for. Of the elements most consistently detected, contents of copper and chromium show the most scatter and gallium the least. A bimodal distribution of chromium is suggested. The plotted frequency distribution has little significance for beryllium, cobalt, nickel, scandium, niobium, and lanthanum, as there are more samples with values below the detectability level than there are with the modal value. The mean differs significantly from the mode for chromium only.

\section{CHANGES IN TRACE-ELEMENT CONTENTS ACROSS THE BATHOLITH}

Lateral variations of major chemical constituents across the central Sierra Nevada batholith have recently been described by 


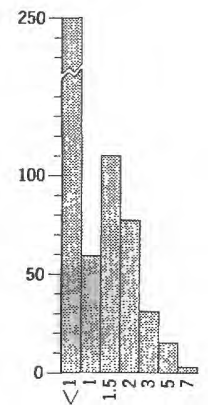

Beryllium 545 determinations
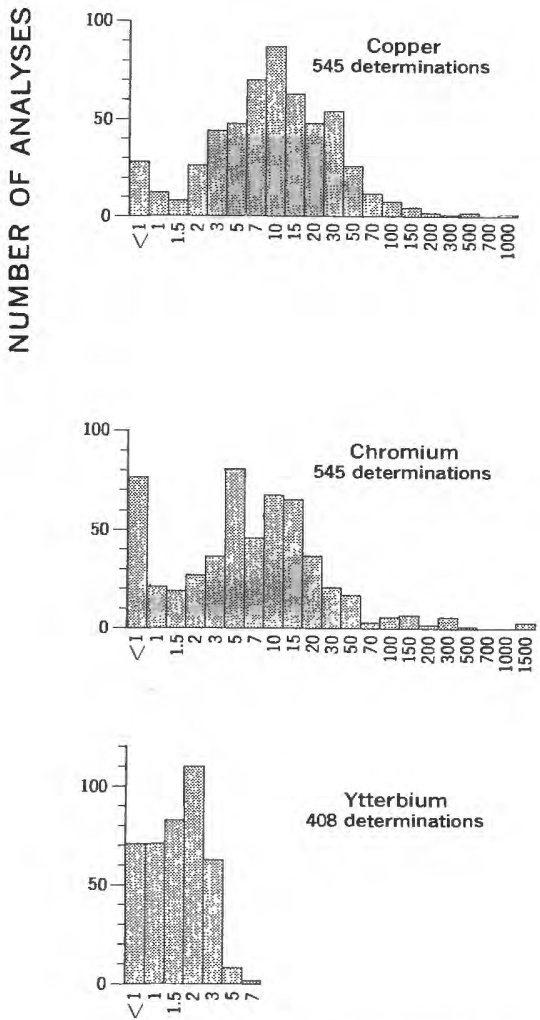
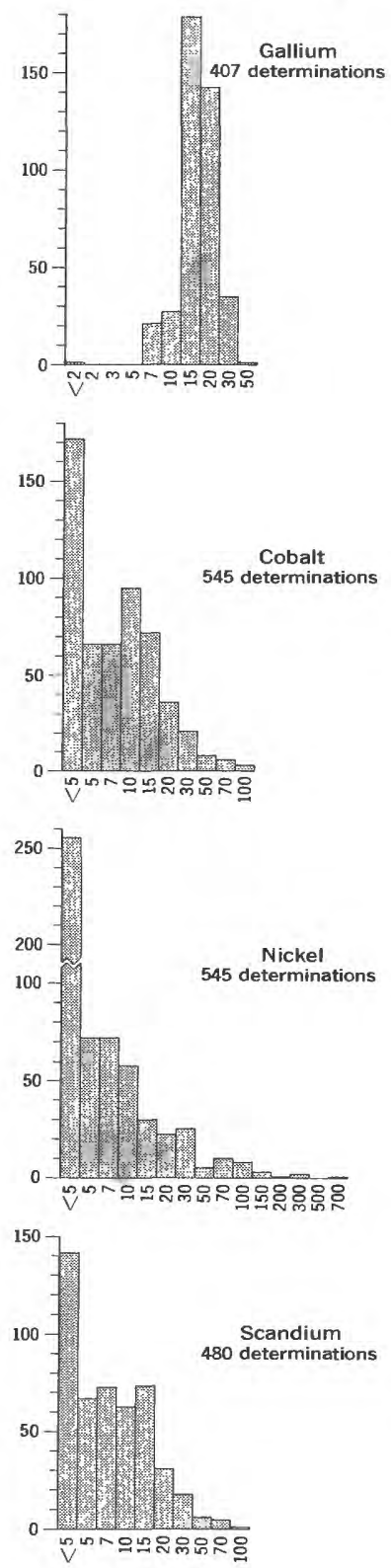

CONCENTRATION, IN PARTS PER MILLION

Figure 2.-Histograms of trace-element contents of plutonic rocks of the Sierra Nevada determined by semiquantitative emission spectrographic analysis. Trace-element concentrations lie within geometric brackets whose 

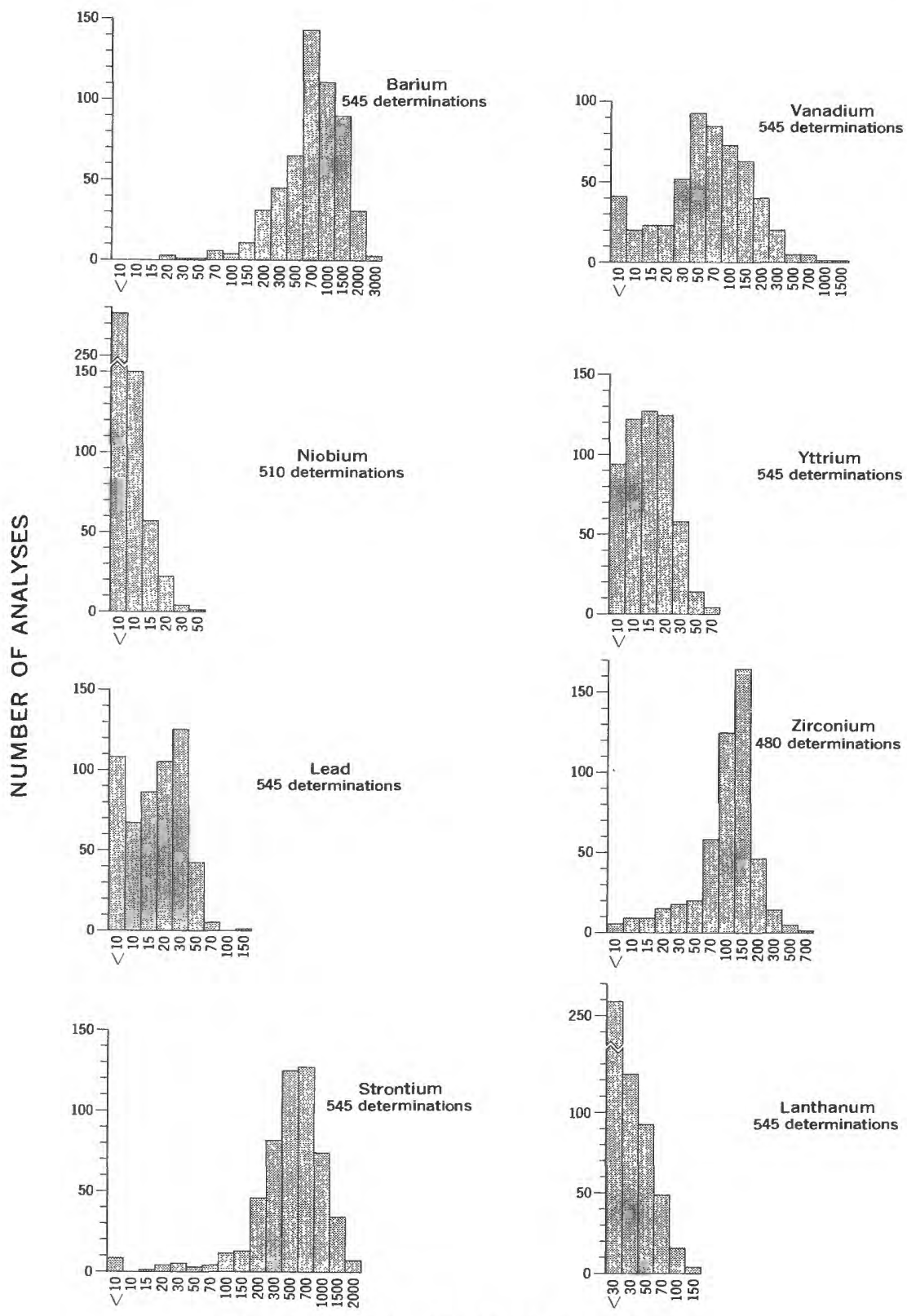

CONCENTRATION, IN PARTS PER MILLION

boundaries are $1.2,0.83,0.56,0.38,0.26,0.18,0.12$ and so forth, but are reported arbitrarily as midpoints of these brackets, that is, $1,0.7,0.5$, $0.3,0.2,0.15,0.1$ and so forth. 
Bateman and Dodge (1970). Semiquantitative spectrographic determination of trace elements has been carried out on 172 of the 193 samples used for the major element study. The samples were collected from 111 carefully identified localities during geologic mapping and are each considered representative of the rocks in the vicinity. Most localities represented by more than one analysis are at heat-flow borehole sites (Lachenbruch, 1968). For the study of geographic variation of trace-element contents, all analyses from the same locality have been averaged. In plate 1 , the semiquantitative trace-element abundances are plotted on a section represented by line $\mathrm{W}-\mathrm{E}$ of figure 1 , a line that crosses the batholith approximately normal to its axis. All of the plots exhibit considerable scatter, and this, together with the sparsity of analyses from the west side of the batholith, makes it difficult to discern trends of trace-element variations across the batholith. Straight lines of the best fit derived by least-squares approximation have been plotted on sections, and correlation coefficients noted. Polynomial curves might fit some of the data slightly better than straight lines, but for merely evaluating possible trends, the first-degree relation should be adequate. Analyses of elements present in amounts less than the detectability level have been given a zero value; in some cases least-squares lines are below the detectability level and have not been plotted.

The eastward increase in beryllium is the only convincing lateral variation. Eastward increase is also vaguely indicated for boron, barium, copper, lanthanum, niobium, lead, strontium, and zirconium. Dodge, Fabbi, and Ross (1970) earlier demonstrated that rubidium tends to increase eastward across the batholith (fig. 3), and plots of both uranium and thorium also show an eastward increase (fig. 4). (The uranium and thorium plots are based in part on data included in publications by Wollenberg and Smith $(1964,1968)$ and in part on unpublished analyses determined by Wollenberg and Smith.) No systematic variations across the batholith are indicated by the plots of cobalt, chromium, gallium, nickel, scandium, vanadium, yttrium, and ytterbium. None of the plots suggest possible significant westward increase of trace elements.

\section{DISCUSSION}

Most of the trace-element averages of plutonic rocks of the Sierra Nevada batholith are quite similar to averages reported by 'Turekian and Wedepohl (1961) for high calcium granites of the earth's crust (table 1). Average contents of gold, yttrium, 


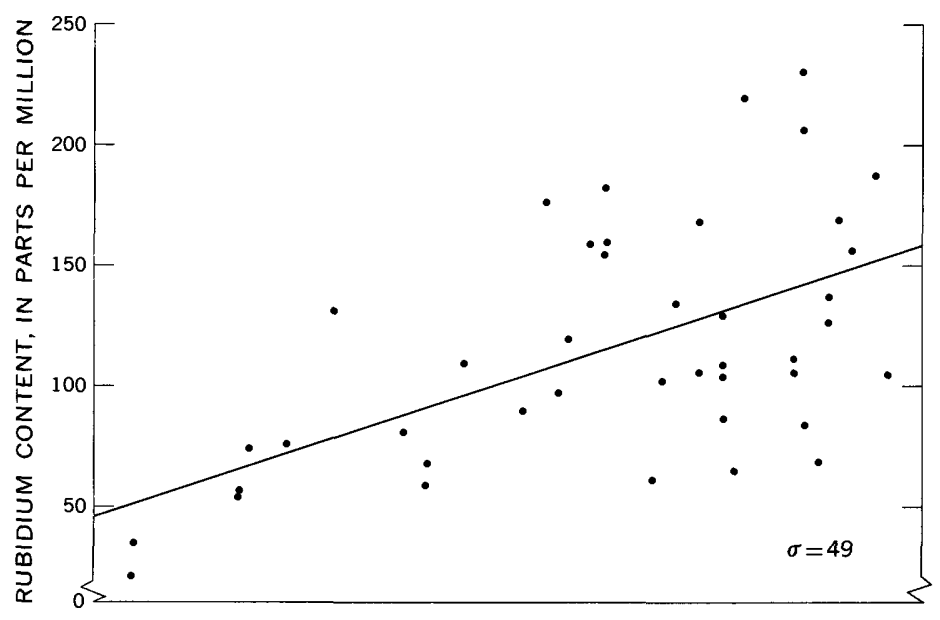

Figure 3.-Rubidium contents of granitic rocks of the central Sierra Nevada batholith projected to line W-E. Line represents least-squares approximation to the formula $y=a x+b$, where $y$ is rubidium content in parts per million and $x$ is the distance along line W-E of figure 1 . The letter $\sigma$ represents one standard deviation from the least-squares line. From Dodge, Fabbi, and Ross (1970).

and ytterbium are somewhat lower for the Sierra Nevada batholith, whereas those of barium, mercury, and thorium are somewhat higher. Close correspondence of the trace-element values is not surprising, particularly in view of the comparable average major-element compositions (table 2). Dickinson (1970), with particular reference to the Sierra Nevada batholith, recently postulated that granitic intrusive magmas may be derived from the same deep sources as andesitic eruptive magmas. For comparison, average trace-element values for circum-Pacific, calcalkaline andesites (Taylor, 1969) are listed in table 1 along with the other averages, and average major element oxide values are listed in table 2 . The graph of relations between minor-element values for the andesites and Sierra Nevada plutonic rocks, figure 5, shows that Sierra Nevada plutonic rocks contain relatively greater amounts of the larger, highly coordinated elements barium, strontium, rubidium, lanthanum, lead, thorium, and uranium than do the andesites.

Average values of many of the other minor elements in Sierran rocks, including vanadium, zirconium, chromium, copper, scandium, cobalt, yttrium, nickel, gallium, and ytterbium, are somewhat less than, or nearly the same as, values for the ande- 

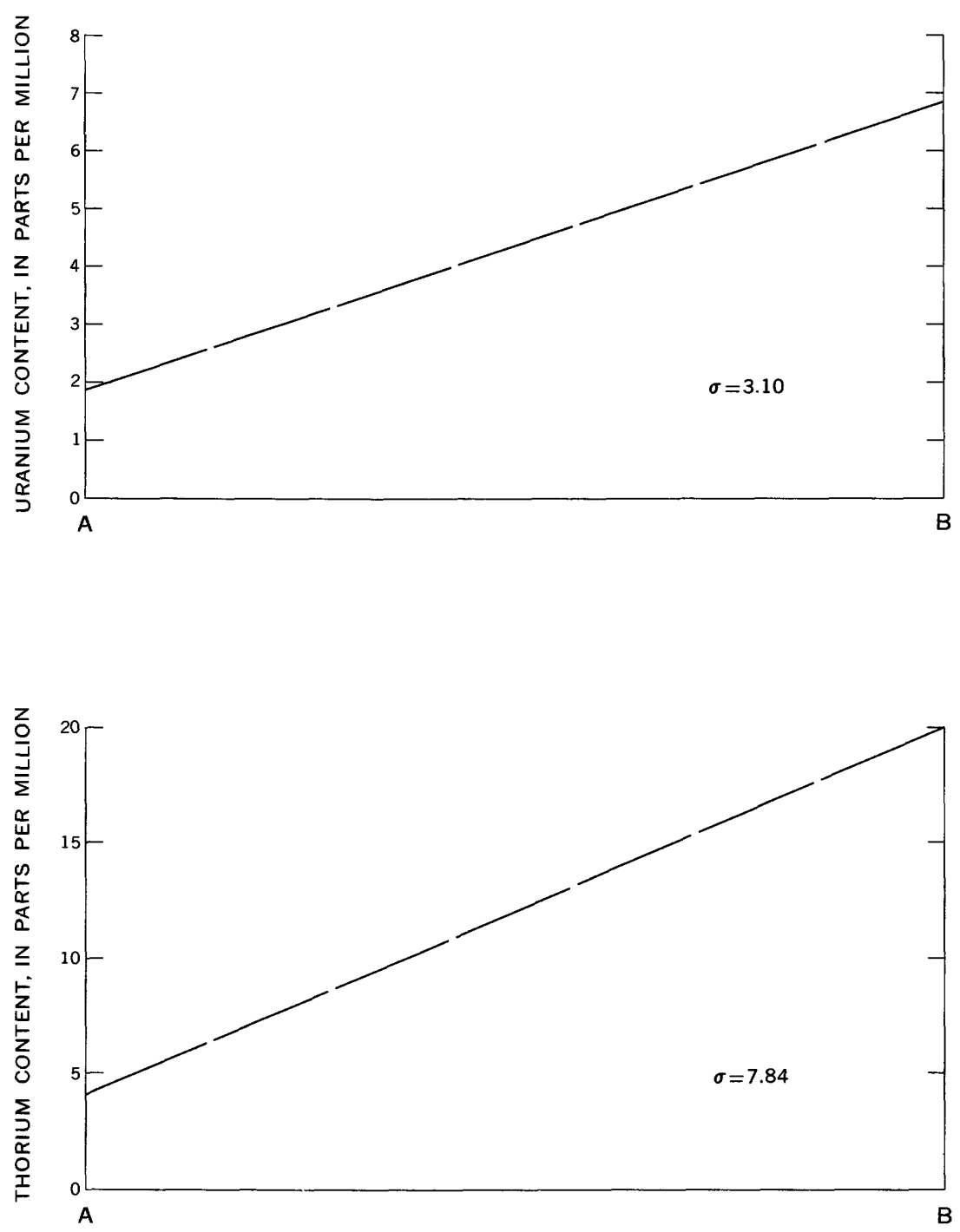

FiguRE 4.-Lines representing least-squares approximations of uranium and thorium contents and distance along line A-B to the formula $y=a x+b$ where $y$ is the element content, $x$ the distance along the line. Line A-B is across the southern part of the central Sierra Nevada belt and has a trend similar to line $\mathrm{W}-\mathrm{E}$ of figure 1 . The letter $\sigma$ represents one standard deviation from the least-squares line. Least-squares approximations are based on 654 determinations of each element. 
TABLE 2.-Average major-element-oxide compositions of Mesozoic plutonic rocks of the Sierra Nevada, high-calcium granites of the earth's crust, and circum-Pacific calc-alkaline andesites

[Data in weight percent]

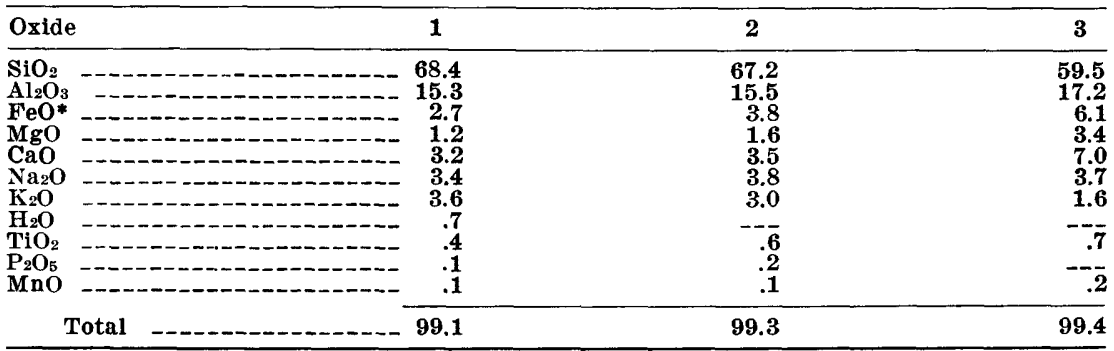

*Total $\mathrm{Fe}$ reported as $\mathrm{FeO}$.

1. Average composition of Mesozoic plutonic rocks of the Sierra Nevada, based on 193 analyses from 132 localities, weighted according to localities.

2. High-calcium granitic rocks of the earth's crust with a mean gross chemical composition of a granodiorite from Turekian and Wedepohl (1961).

3. Average composition of circum-Pacific calc-alkaline andesites compiled by Taylor (1969).

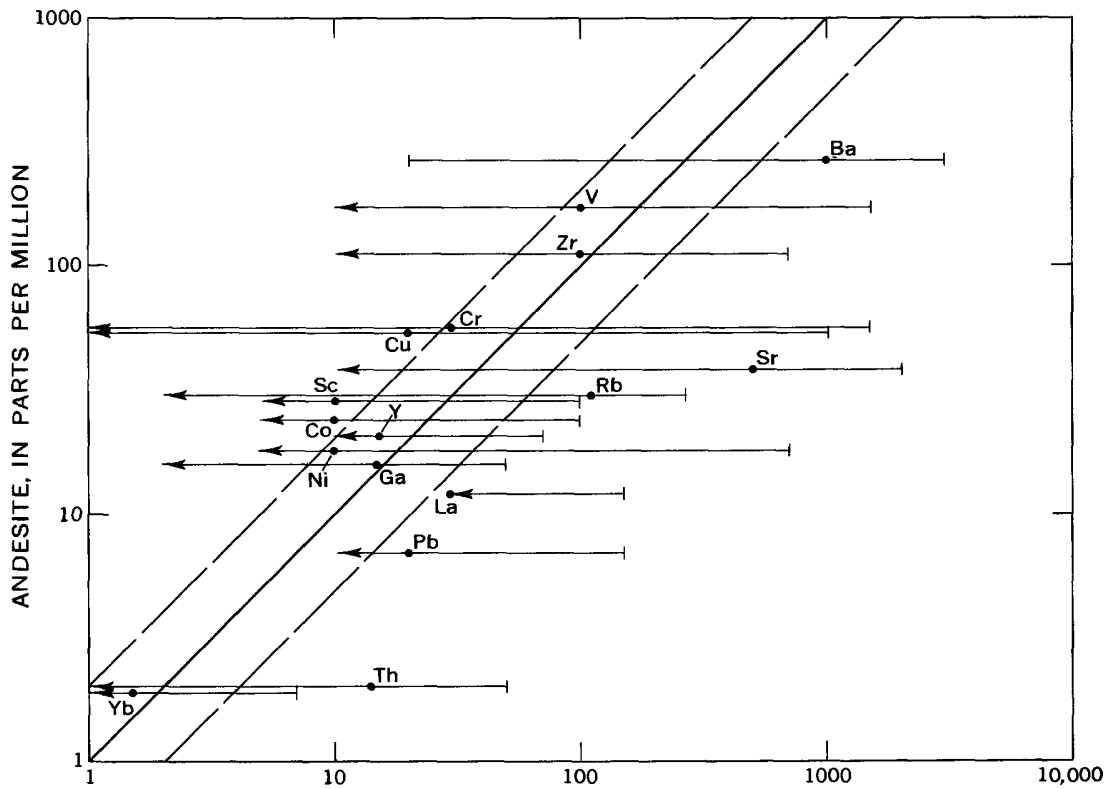

SIERRA NEVADA PLUTONIC ROCKS, IN PARTS PER MILLION

FIgURE 5.-Comparison of average and ranges of trace-element contents of plutonic rocks of the Sierra Nevada batholith and average contents of circum-Pacific andesites (from Taylor, 1969). Solid circle is average value; horizontal line represents range of trace-element content in the plutonic rocks; arrowhead indicates detectability level if some values are below the level. The solid oblique line represents correspondence of the two averages. Dashed lines represent values within a factor of two of correspondence of compositions. Abundance outside these limits is probably different. 
sites; with one or two exceptions, these elements occur in sixfold coordination positions in silicates. Ranges of almost all traceelement contents of the batholith overlap the andesite averages. These trace-element data are consistent with the hypothesis that Sierran granitic magmas were derived by fractional crystallization from the same type of sources as-were andesitic lavas, for processes of fractional crystallization or magmatic differentiation normally result in concentration of large, highly coordinated cations. On the other hand, derivation of Sierran plutonic rocks from other sources, such as anatexis of relatively fusible crustal rocks (Bateman and Eaton, 1967) with or without fractional crystallization, cannot be ruled out on the basis of trace-element abundances.

Causes of lateral variations of trace elements across the central Sierra Nevada batholith, particularly the prominent systematic eastward increase of beryllium, rubidium, thorium, and uranium, are incompletely known. Undoubtedly these variations are related to the compositional changes of major chemical constituents, particularly of $\mathrm{K}_{2} \mathrm{O}$, that also take place across the batholith (Bateman and Dodge, 1970). Wollenberg and Smith (1969) have found that prebatholithic rocks show eastward increase of potassium, uranium, and thorium, suggesting that the intrusive magmas may have formed at least in part by the fusion of the prebatholithic rocks. The trends noted here may thus be a reflection of crustal chemical variation which existed before batholith emplacement.

\section{REFERENCES CITED}

Bateman, P. C., 1965, Geology and tungsten minecalization of the Bishop district, California: U.S. Geol. Survey Prof. Paper 470, 208 p.

Bateman, P. C., Clark, L. D., Huber, N. K., Moore, J. G., and Rinehart, C. D., 1963, The Sierra Nevada batholith-a synthesis of recent work across the central part: U.S. Geol. Survey Prof. Paper 414-D, p. D1-D46.

Bateman, P. C., and Dodge, F. C. W., 1970, Variations of major chemical constituents across the central Sierra Nevada batholith: Geol. Soc. America Bull., v. 81, p. 409-420.

Bateman, P. C., and Eaton, J. P., 1967, Sierra Nevada batholith: Science, v. 158 , p. $1407-1417$.

Bateman, P. C., and Lockwood, J. P., 1970, Kaiser Peak quadrangle, central Sierra Nevada, California-analytic data: U.S. Geol. Survey Prof. Paper 644-C, p. C1-C15.

Bateman, P. C., and Wones, D. R., 1972, Huntington Lake quadrangle, central Sierra Nevada, California-analytical data: U.S. Geol. Survey Prof. Paper 724-A. (In press.) 
Dickinson, W. R., 1970, Relations of andesites, granites, and derivative sandstones to arc-trench tectonics: Rev. Geophys. Space Phys., v. 8, p. 813-860.

Dodge, F. C. W., Fabbi, B. P., and Ross, D. C., 1970, Potassium and rubidium in granitic rocks of central California, in Geological Survey research 1970 : U.S. Geol. Survey Prof. Paper 700-D, p. D108-D115.

Dodge, F. C. W., and Fillo, P. V., 1967, Mineral resources of the Desolation primitive area of the Sierra Nevada, California: U.S. Geol. Survey Bull. 1261-A, p. A1-A27.

Gottfried, David, Rowe, J. J., and Tilling, R. I., 1972, Distribution of gold in igneous rocks: U.S. Geol. Survey Prof. Paper 727, 42 p.

Lachenbruch, A. H., 1968, Preliminary geothermal model of the Sierra Nevada: Jour. Geophys. Research, v. 73, p. 6977-6989.

Lockwood, J. P., Bateman, P. C., and Sullivan, J. S., 1972, Mineral resource evaluation of the U.S. Forest Service Sierra Demonstration Project area, Sierra National Forest, California: U.S. Geol. Survey Prof. Paper 714. (In press.)

Ross, D. C., 1969, Descriptive petrography of three large granitic bodies in the Inyo Mountains, California: U.S. Geol. Survey Prof. Paper 601, $47 \mathrm{p}$.

Taylor, S. R., 1969, Trace element chemistry of andesites and associated volcanic rocks, in McBirney, A. R., ed., Proceedings of the Andesite Conference: Oregon Dept. Geology and Mineral Industries Bull. 65, p. $43-63$.

Tooker, E. W., Morris, H. T., and Fillo, P. V., 1970, Mineral resources of the Emigrant Basin primitive area, California: U.S. Geol. Survey Bull. 1261-G, p. G1-G70.

Turekian, K. K., and Wedepohl, K. H., 1961, Distribution of the elements in some major units of the earth's crust: Geol. Soc. America Bull., v. 72 , p. $175-192$.

Wollenberg, H. A., and Smith, A. R., 1964, Radioactivity and radiogenic heat in Sierra Nevada plutons: Jour. Geophys. Research, v. 69, no. 16, p. $3471-3478$.

1968, Radiogeologic studies in the central part of the Sierra Nevada batholith, California: Jour. Geophys. Research, v. 73, no. 4, p. 1481-1495. 1970 , Radiogenic heat production in prebatholithic rocks of the central Sierra Nevada: Jour. Geophys. Research, v. 75, p. 431-438. 


